\title{
A MULTI-CRITERIA DECISION-MAKING SYNTHESIS METHOD TO DETERMINE THE MOST EFFECTIVE OPTION FOR MODERNISING A PUBLIC BUILDING
}

\author{
Jovita STARYNINA ${ }^{1}$, Leonas USTINOVICHIUS $2^{2 *}$ \\ ${ }^{1}$ RB Rail AS, Konstitucijos pr. 21, Vilnius, Lithuania \\ ${ }^{2}$ Faculty of Engineering Management, Bialystok University of Technology, \\ Bialystok, ul. Ojca Tarasiuka 2, 16-001, Kleosin, Poland
}

Received 01 April 2020; accepted 14 June 2020

\begin{abstract}
The study presents a sustainable building modernisation model that uses knowledgebased decision-making methods to general reconstruct old public buildings, intending to achieve the best level of energy use on the design scene. The rapid development and dissemination of standards cause multiple research opportunities in the fields of process automation and adaptation of BIM technologies to the prerequisites of existing buildings. Decision-making was widely supported by imitating structures used in the late stages of design. However, its application is not sufficient at the beginning, which affects design solutions with a significant impact on the performance of the completed building. Construction design is a multifaceted discipline where architects, engineers, contractors, and builders influence design decisions. This modernisation way uses digital systems and simulations to estimate the expected energy consumption of construction faster and economically. BIM and critical characteristics are the basis of the model, where design and general processing needs to follow to pre-built instructions. This solution allows estimating energy demand in reconstructed buildings and correlation of parameters.
\end{abstract}

Keywords: sustainable, energy, MCDM, BIM, decision making.

JEL Classification: C3, Q4, Q5.

\section{Introduction}

A more detailed analysis of the development of the construction economy shows that in the 21 st century, property management has shifted from near-exceptional growth and construction consumption to critical types of sustainability, namely economic growth, social development, and environmental protection (Jia et al., 2019; Zou et al. 2017). Modern and responsible leaders are looking for practical, innovative, and at the same time, sustainable solutions for new initiatives and projects (Zemlickienè \& Turskis, 2020; Nazarko \& Mel-

*Corresponding author. E-mail: leonas959@gmail.com

Copyright (c) 2020 The Author(s). Published by Vilnius Gediminas Technical University

This is an Open Access article distributed under the terms of the Creative Commons Attribution License (http://creativecommons. org/licenses/by/4.0/), which permits unrestricted use, distribution, and reproduction in any medium, provided the original author and source are credited. 
nikas, 2019; Winkowski, 2019). In today's world, plans to be implemented in one country affect plans and projects to be implemented in other countries. Besides, the decision and implementation of the project will influence every project already implemented and decisions made by other managers regarding plans. That is, the environment changes with each project (Zavadskas et al., 2009).

On the one hand, construction-marketing initiatives can be successful, socially responsible (Mahdiraji et al., 2019), and sustainable (Ruzgys et al., 2014). On the other hand, they can sometimes are as a waste of resources and negative environmental impact. Thus, in the future, the solutions chosen must be practical and well balanced, both locally and globally (Hashemkhani Zolfani et al., 2013). The European Commission Communication "Strategy for the sustainable competitiveness of the construction sector and its enterprises" (2012) recognises that the EU construction sector plays an essential role in the European economic development as it generates almost $10 \%$ of GDP and provides 20 million jobs. The EU states must ensure that since 2019, all newly constructed public buildings. While, since 2021, all new buildings should be nearly zero-energy buildings (European Union, 2010). The European countries have been long developing the application of Building Information Modelling (BIM) for new construction (European Commission, 2012).

Buildings considerably impact on the health and well-being of people and the environment. Old buildings use unsustainable resources. Besides, they generate a significant amount of waste and are too expensive to maintain and operate. Buildings with zero-waste can only be achieved ensuring that design of building, construction processes and operation phase increase productivity and decreases energy consumption, use fewer resources also it reduces the amount of waste and the impact on the environment as well as reduce costs during the lifecycle. The Energy Roadmap 2050 and 2030 EU Climate and Energy Framework insist on more focus on the energy efficiency of the housing sector due to the reason that it is the biggest user of energy in Europe, counting for almost $40 \%$ of the all energy consumption (European Commission, 2011b, 2014; European Union, 2010).

Nowadays, sustainability in real estate is a crucial topic; however, the energy performance of buildings received much attention over the last decades. Due to the negative impact of buildings on the environment, which is the responsibility of the construction industry, the demand for sustainable buildings is increasing (Jose et al., 2019; Jensen et al., 2018, Chalal et al., 2020). Policymakers make the majority of critical decisions related to energy even before the design process starts (Chong et al., 2017; Kreider et al., 2010; Pinheiro et al., 2018; Somboonwit et al., 2017).

Predicting the energy performance of buildings often accomplishes the design of buildings with reduced energy use (Habibi, 2017; Hemsath \& Bandhosseini, 2017). Information exchange between the energy modelling of structures and their design has many problems, including defects in the parameters of object information, geometric false images, and the confusion of re-entry data (Garcia \& Zhu, 2015). The main problem faced by the modernisation of old buildings is that it must be preceded by documentation review and information analysis of different lifecycle stages as well as involving architects, constructors, users, and administrators (Linderoth, 2010). It takes a lot of time and effort to evaluate the existing situation (Bortolini \& Forcada, 2018). A fundamental challenge within the field of renovation 
is handling enormous complexity (Kamari et al., 2019). The number of existing buildings that require renewal justifies the need for the modernisation model that optimises their life following the renovation (Rodrigues et al., 2018).

Decision-makers need methodologies to assess the performance level of buildings modernisation to address the comparison of different alternatives based on their efficiency and quality (Kreiner et al., 2015; Turskis et al., 2013).

The construction sector intensified the adaptation of BIM for construction due to countless positive aspects, such as resource savings during the design, planning and development of new buildings (Leite et al., 2011; Gray et al., 2013). BIM is one of the prospective changes in the construction industry (Salman, 2011). To analyse the condition of old buildings as well as the application of modernisation principles aiming to achieve a specific energy efficiency class after modernisation, a shortage of normative documents describing the process must be addressed. Currently, the undertaken process of building modernisation is complicated and unstructured. It demands the assessment of a variety of different engineering systems and needs a methodology to determine economic and environmental benefits anticipated from building modernisation.

The design, construction and operation of buildings shall aim to ensure full energy consumption in line with the principle of sustainable and energy-efficient development. They seek to achieve higher efficiency and lower energy consumption, fewer resources, less waste and minimal environmental impact, as well as reduce the cost of a building during its life cycle (Wang \& Adeli, 2014; Žèkas et al., 2014).

Strategic energy documents of the EU insist on placing greater emphasis on promoting the efficiency of energy consumption in the building management sector as inefficient buildings account for about $40 \%$ of consumed energy in Europe (European Union, 2010; European Commission, 2011a, 2014).

The requirement to construct and renovate nearly zero-energy buildings necessitates the construction sector to improve its working practices by applying new technologies and methods. In the construction industry, several factors - such as working methods, large numbers of companies and a relative shortage of quality standards, inspection protocols and guidelines - contribute to limited significant energy efficiency investments and their impact as well as effective integration of renewable energy sources ( $\mathrm{Hu}, 2019)$. According to research, a forecast of energy consumption by a building must be considered as early as during the design stage (Mahdavi \& Tahmasebi, 2015; Martinaitis et al., 2015).

BIM is a collaboration method based on digital technologies that are easier and more effectively adapted during the design stage (Bryde et al., 2013). A digital model of a building is adapted for use 0 sal to the finished construction and maintenance (Jung \& Joo, 2011). Policymakers mostly used processes based on BIM for newly designed buildings and infrastructure projects. At the same time, they only a few of them used for already existing structures, their maintenance, and in the process of modernisation (Merschbrock \& Figueres-Munoz, 2015). The whole building's life cycle (from design and construction phases until facility management processes) needs BIM technologies. Advantages of BIM use in construction are progressively applied in the architecture, construction industry due to their many profits to project stakeholders as they can review design visualisations, it also improves information 
exchanges, lowers wastes of construction and gives a higher quality of the processes (Yin et al., 2019). However, not all capabilities of BIM is enabled, such as facility management remains in its infancy (Edirisinghe et al., 2017). However, they are potential in reconstruction projects. There additional information flows, such as laser scanning for the assessment of an existing building and active investigation of energy efficiency and cost-effectiveness assessment, need management: (Lee et al., 2015; Barlish \& Sullivan, 2012).

Researcher Volk et al. (2014) introduced a revision of 180 publications regarding BIM topic in buildings. The results demonstrate the sluggish application of BIM technologies for existing buildings (Gu \& London, 2010).

Many researchers and economists recognise the significance of multi-criteria decision-making (MCDM) methods. Some of the scientists applied these methods to solve complex decisions in a variety of areas such as health risk assessment (Habib et al., 2019), intelligent systems (He \& Xu, 2019), and analysis of statistical data (Krylovas et al., 2018). Other researchers using MCDM methods measured performance of achievements (Zavadskas et al., 2013; Maghsoodi et al., 2018), sustainable energy development (Siksnelyte et al., 2018), and ranked options of supply chain management (Yazdani et al., 2019). The MCDM methods were useful to solve transport (Radović et al., 2018), energy efficiency (Kaya et al., 2018), and renewable energy (Kumar et al., 2017), green technologies (Banasik et al., 2018), in the choice of sustainable materials (Govindan et al., 2016; Ilce \& Ozkaya, 2018), and other problems. These researches prove that MCDM methods are useful tools in finding the right solutions to modern business problems. Hybrid MCDM approach consists of MCDM methods. Zavadskas et al. (2016a, 2016b) identified four groups of hybrid MCDM methods to calculate the relative value of criteria and prioritise identified alternatives.

\section{Development of the algorithm for the optimisation model}

The implementation of the optimisation model requires dividing it into separate assessment processes, which are necessary to create building elements energy simulations. To achieve the proper energy performance of a building, designers need to determine its current energy efficiency class. The work should start by determining key energy parameters of structural partitions and engineering systems of the analysed building. The energy efficiency class of the building is determined using a reverse task (Figure 1).

In terms of energy performance, buildings fall into nine categories: $A++, A+, A, B, C$, and others (STR 2.01.02:2016). The work should start by determining key energy parameters of structural partitions and engineering systems of the analysed building. The energy efficiency class of the public building is determined by applying a reverse task (Figure 1).

One significant component of a knowledge-based management system is the optimisation subsystem that comprises tools for advanced selection of alternatives and decision-making at the conceptual Stage as well as measures used after the energy analysis of the additional model. The conceptual phase of the project further develops the logic of the inverse problem algorithm by choosing predefined alternatives. Designers should identify variants of structural and engineering systems that are consistent with the energy efficiency class defined in the choice of retrofitting the building plan. Experts checking the building and its energy per- 


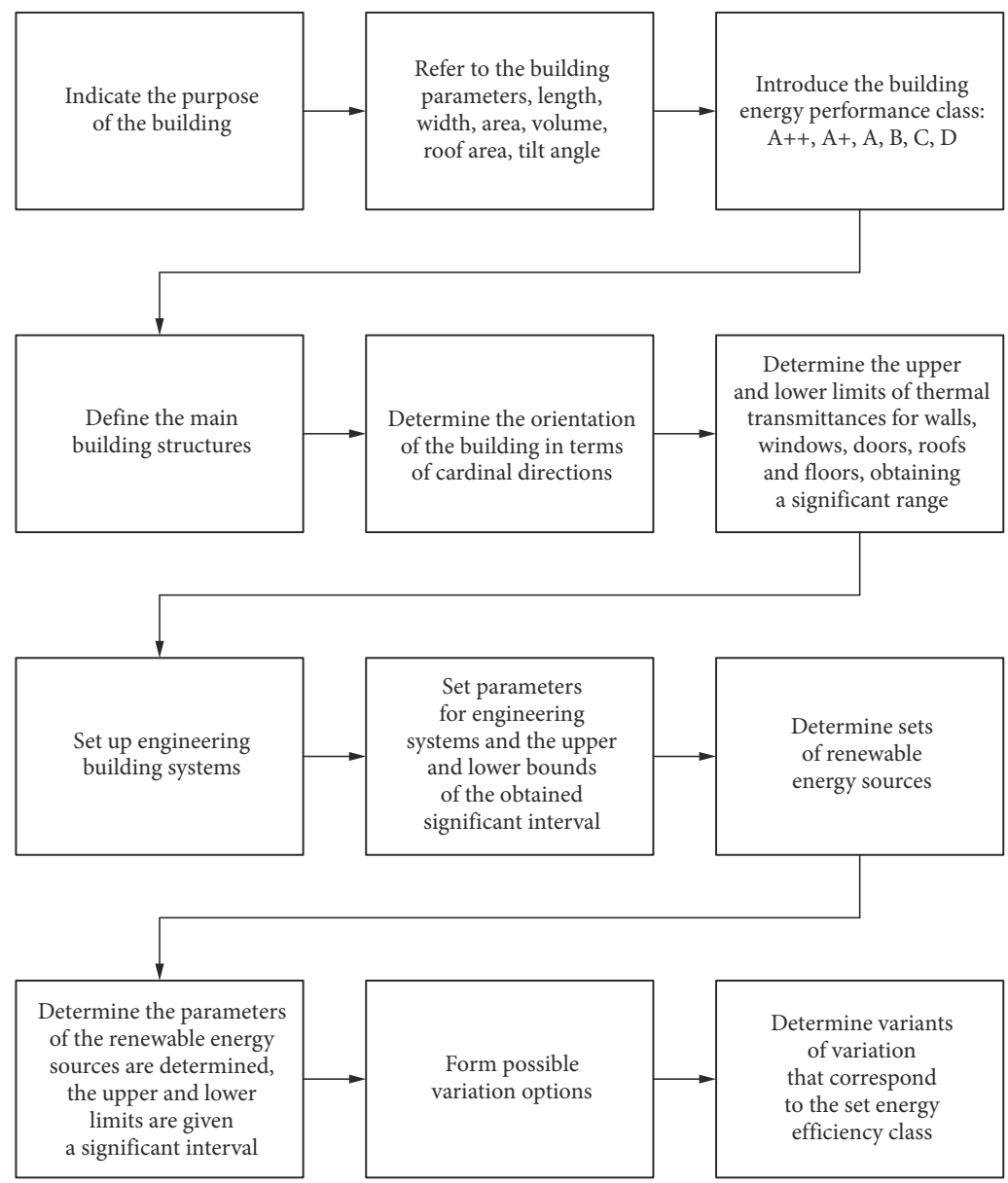

Figure 1. Reverse energy task of consumption

formance collect all the data needed to describe the current state of the building. A database stores the collected data. Data about energy consumption and design decisions justify the need and scope of modernisation. The experts and the building stakeholders shall establish and define criteria for the effectiveness of the building retrofit measures. Experts substantiate the values and weights of the characteristics with pairwise comparisons.

There is no automated optimisation model for this reason. Besides, integrating it into the BIM system entirely needs significant resources. Therefore, the study proposes a mathematical optimisation model (Figure 2) with the manually collected input data.

Figure 2 indicates the split of the optimisation model into two stages:

- Stage I determines key thermal transmittances of structural partitions and efficiencies of engineering systems;

- Stage II uses the results of Stage I to determine the most effective solutions to alternatives that conforms to the energy efficiency class. 


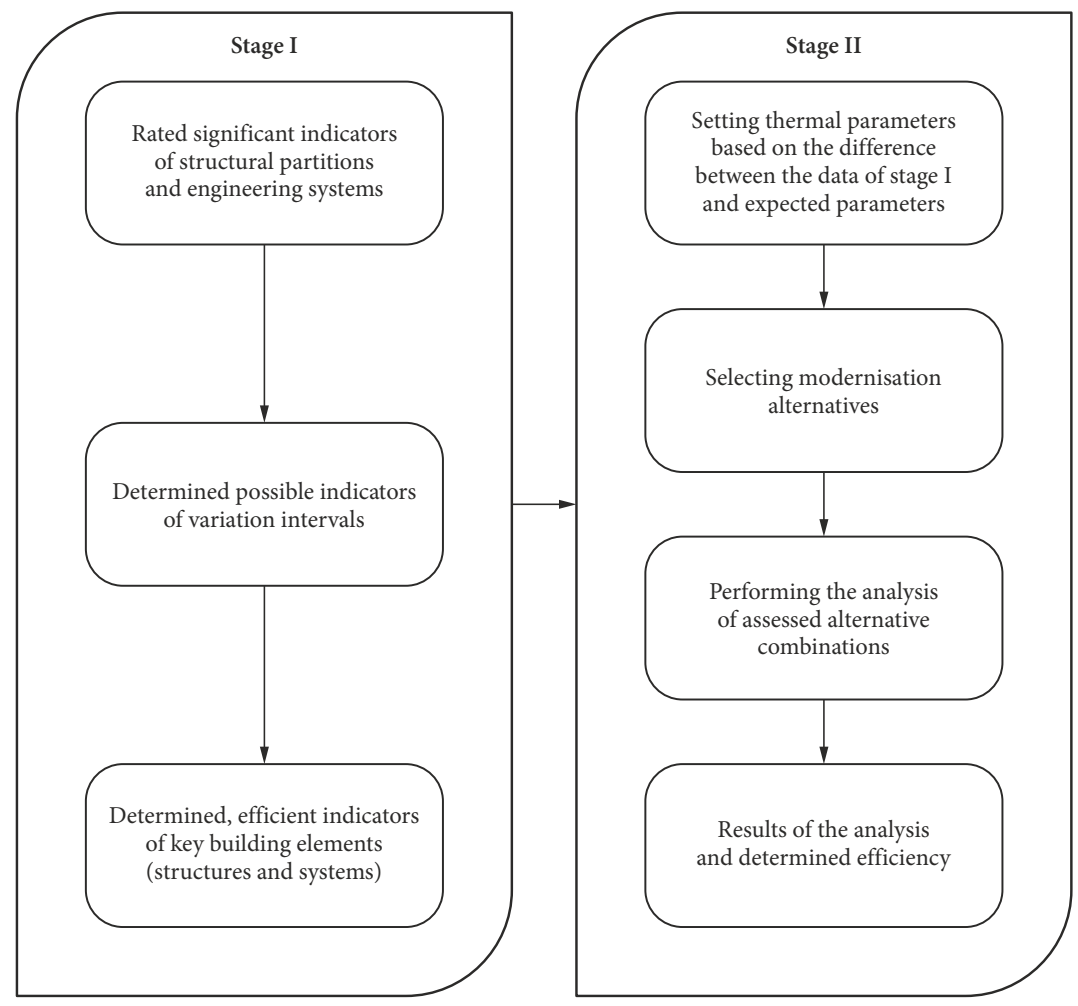

Figure 2. Optimisation model

During the Stage I, the assessment focused on the maximum roof thermal transmittance $-U_{s t \text { max }}$; the minimum thermal transmittance of the roof $-U_{s t \text { max }}$; the mean thermal transmittance of the roof $-U_{s t 0}$; the significant interval of the thermal transmittance of the roof $-\Delta U_{s t}$; the maximum thermal transmittance of the basement floor $-U_{g r \text { max }}$; the minimum thermal transmittance of the basement floor $-U_{g r \text { max }}$; the mean thermal transmittance of the basement floor $-U_{g r 0}$; the significant interval of the thermal transmittance of the basement floor $-\Delta U_{g r}$; the maximum thermal transmittance of walls $-U_{\text {sien max }}$; the minimum thermal transmittance of walls $-U_{\text {sien max }}$; the mean thermal transmittance of walls $-U_{\text {sien } 0}$; the significant interval of the thermal transmittance of walls $-\Delta U_{\text {sien }}$; the maximum thermal transmittance of doors and windows $-U_{l a n \text { max }}$; the minimum thermal transmittance of doors and windows - $U_{\text {lan max }}$; the mean thermal transmittance of doors and windows $U_{\text {lan } 0}$; the significant interval of the thermal transmittance of doors and windows $-\Delta U_{\text {lan }}$.

Besides, several coefficients were formed. Namely, the maximum efficiency of the ventilation system $-\eta_{\text {re max }}$; the minimum efficiency of the ventilation system $-\eta_{\text {re max }}$; the mean efficiency of the ventilation system $-\eta_{\text {re } 0}$; the significant interval of the ventilation system $\Delta \eta_{r e}$; the heating system source (central system, gas boiler, electricity, and others) $-S_{\text {sist }}$ is determined as well as the hot water source (central system, gas boiler, power, and others) $V_{\text {sist }}$, the cold air source (refrigeration chambers, air conditioners, and others) $-O_{\text {sist }}$, and the source of renewable energy $-A_{\text {sist }}$. 
The investigation analysed six affecting factors: the thermal transmittance of the roof, the thermal transmittance of the basement floor (plinth), the thermal transmittance of walls, the thermal transmittance of doors and windows, ventilation system efficiency, and the indoor consumption of energy.

In the following cases, the analysis produced three levels of values, namely, lower, mean and upper, for the thermal transmittance of the roof $(0.15 ; 0.2 ; 0.25)$; the thermal transmittance of the basement floor (plinth) $(0.25 ; 0.3 ; 0.35)$; the thermal transmittance of walls $(0.2$; $0.25 ; 0.3)$; the thermal transmittance of doors and windows $(1.2 ; 1.6 ; 2)$; and ventilation system efficiency $(0.7 ; 0.8 ; 0.9)$.

The calculation of all coefficients resulted in 243 variants. Due to a large number of options, the use of dispersion analysis methods became impracticable; thus, for experiments, the full factorial analysis technique was useful. Table 1 presents the main level of indicators with variation intervals. Table 2 demonstrates the full factorial experiment matrix under conditions of developed energy simulations for building elements (Goh, 1989). The planning matrix shows all possible combinations of lower and upper levels for each affecting factor.

Table 1. Key indicators of the planning matrix

\begin{tabular}{|c|c|c|c|c|c|c|}
\hline 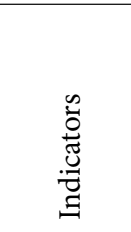 & 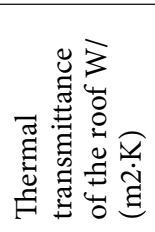 & 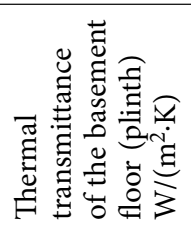 & 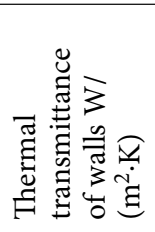 & 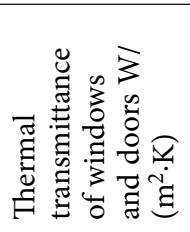 & 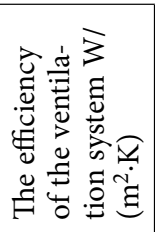 & 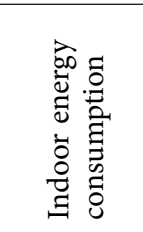 \\
\hline $\begin{array}{l}\text { Main } \\
\text { level }\end{array}$ & 0.2 & 0.25 & 0.25 & 1.6 & 0.8 & calculated \\
\hline $\begin{array}{l}\text { Variation } \\
\text { interval }\end{array}$ & 0.05 & 0.05 & 0.05 & 0.4 & 0.1 & - \\
\hline
\end{tabular}

Table 2. Key indicators (Goh, 1989)

\begin{tabular}{|c|c|c|c|c|c|c|}
\hline \multirow{2}{*}{ Experiment No. } & \multicolumn{5}{|c|}{ Affecting factors } & \multirow[t]{2}{*}{ Optimisation parameters } \\
\hline & $\mathrm{X} 1$ & $\mathrm{X} 2$ & $\mathrm{X} 3$ & $\mathrm{X} 4$ & $\mathrm{X} 5$ & \\
\hline 1 & $-\mathrm{I}$ & $-\mathrm{I}$ & $-\mathrm{I}$ & $-\mathrm{I}$ & $-\mathrm{I}$ & Y1 \\
\hline 2 & $\mathrm{I}$ & $-\mathrm{I}$ & $-\mathrm{I}$ & $-\mathrm{I}$ & $-\mathrm{I}$ & Y2 \\
\hline 3 & $+\mathrm{I}$ & $-\mathrm{I}$ & $-\mathrm{I}$ & $-\mathrm{I}$ & $-\mathrm{I}$ & Y3 \\
\hline 4 & $-\mathrm{I}$ & I & $-\mathrm{I}$ & $-\mathrm{I}$ & $-\mathrm{I}$ & Y4 \\
\hline 5 & I & I & $-\mathrm{I}$ & $-\mathrm{I}$ & $-\mathrm{I}$ & Y5 \\
\hline 6 & $+\mathrm{I}$ & I & $-\mathrm{I}$ & $-\mathrm{I}$ & $-\mathrm{I}$ & Y6 \\
\hline 7 & $-\mathrm{I}$ & $+\mathrm{I}$ & $-\mathrm{I}$ & $-\mathrm{I}$ & $-\mathrm{I}$ & \\
\hline \multicolumn{7}{|c|}{$\vdots$} \\
\hline 234 & $+\mathrm{I}$ & $+\mathrm{I}$ & $+\mathrm{I}$ & I & $+\mathrm{I}$ & \\
\hline
\end{tabular}


The upper bound of the thermal transmittance of structural partitions was accepted on the condition that its further increase would have failed to confirm the variant of the B class NRG requirements for a building. The lower bound was accepted on the condition that a lower value of the thermal transmittance would have meant an increase in the price of structural partitions.

The upper bound of the efficiency of the ventilation system was accepted to be 0.9 (W/ $\left(\mathrm{m}^{2} \cdot \mathrm{K}\right)$ as any further increase in the efficiency would have failed to correspond to the variant of the class B NRG building. The lower bound was accepted to be $0.7\left(\mathrm{~W} /\left(\mathrm{m}^{2} \cdot \mathrm{K}\right)\right.$ as any lower value of the efficiency would have meant an increase in the price of the ventilation system.

Following the plan, the analysis of the method used to develop energy simulations of building elements focused on the following attributes (later, the characteristics became efficiency indicators):

- $Y 1=U_{r o}$ - the thermal transmittance of the roof;

- Y2 $=U_{f l}$ - the thermal transmittance of the basement floor;

- Y3 $=U_{w a}$ - the thermal transmittance of walls;

- $Y 4=U_{\text {win }}$ - the thermal transmittance of windows and doors;

- Y5 $=\eta_{v e n}$ - the efficiency of the ventilation system;

- Y $\sigma_{i}(i=1.243)=f\left(U_{r o}, U_{f f}, U_{w a}, U_{w i n}, \eta_{v e n}, S_{\text {sist }}, V_{\text {sist }}, O_{\text {sist }}, A_{\text {sist }}\right)$ - the NRG class and indoor energy consumption (determined using listed indicators and rejecting non- $\mathrm{B}$ class variants).

Table 3 provides the developed decision-making matrix $X$.

The SAW (Simple Additive Weighting) method helped to determine the rationality of variants using a matrix. Simple Additive Weighting is the best known and the most popular method, which is also one of the simplest. MacCrimmon (1968) offered the summary of the method rules.

Initial data - the decision matrix and significance values. The decision matrix cannot have non-numerical values.

Table 3. Decision-making matrix

\begin{tabular}{|c|c|c|c|c|c|c|}
\hline \multirow[b]{2}{*}{$\begin{array}{c}\text { Variation } \\
\text { alternatives }\end{array}$} & \multicolumn{6}{|c|}{ Indicators (thermal transmittances) } \\
\hline & $\begin{array}{l}\text { Roof } \\
(Y 1) \\
\left(U_{s t}\right)\end{array}$ & $\begin{array}{c}\text { Basement floor } \\
(Y 2) \\
\left(U_{g r}\right)\end{array}$ & $\begin{array}{l}\text { Walls } \\
(Y 3) \\
\left(U_{\text {sien }}\right)\end{array}$ & $\begin{array}{l}\text { Windows, } \\
\text { doors } \\
(Y 4) \\
\text { (Ulan) }\end{array}$ & $\begin{array}{l}\text { Ventilation } \\
\text { system } \\
(Y 5) \\
(\eta \mathrm{re})\end{array}$ & $\begin{array}{c}\text { Energy } \\
\text { consumption } \\
\mathrm{kWh} / \mathrm{m}^{2} \times \text { years } \\
(Y 6)\end{array}$ \\
\hline 1 & $U_{s t \min }$ & $U_{f l \min }$ & $U_{w a \min }$ & $U_{\text {win } \min }$ & $\eta_{\text {ven } \min }$ & $\mathrm{Y}_{1}$ \\
\hline 2 & $U_{r o 0}$ & $U_{f l \min }$ & $\mathrm{U}_{\text {wa min }}$ & $U_{\text {win } \min }$ & $\eta_{\text {ven } \min }$ & $Y 6_{2}$ \\
\hline \multicolumn{7}{|c|}{$\vdots$} \\
\hline 234 & $U_{\text {ro } \max }$ & $U_{f l \max }$ & $U_{w a 0}$ & $U_{\text {win } \max }$ & $\eta_{\text {ven } \max }$ & $Y 6_{234}$ \\
\hline $\begin{array}{l}\min \text { or } \max \\
\text { indicator }\end{array}$ & $\min$ & $\min$ & $\min$ & $\min$ & $\max$ & $\min$ \\
\hline $\begin{array}{l}\text { Significance } \\
\text { of the } \\
\text { indicator }\end{array}$ & 1 & 1 & 1 & 1 & 1 & 1 \\
\hline
\end{tabular}


Initial data is the decision matrix and significances of each effectiveness indicator

$$
\bar{q}=\left\{\bar{q}_{1}, \bar{q}_{2}, \ldots, \bar{q}_{n}\right\}
$$

Identifying the rationality of a variant, respective members of the normalised matrix are multiplied by significances and summed. The sum of the rational variant multiplications will be maximal:

$$
A=\left\{A_{i} \mid \max _{i} \sum_{j=1}^{n} \bar{q}_{j} \bar{x}_{i j} / \sum_{j=1}^{n} \bar{q}_{j}\right\},
$$

here, $\bar{x}_{i j}$ - normalised decision-making matrix.

The second Stage identifies the measures (structural solutions) that can be used to achieve the solution was determined in the first phase. Experts and the manager of the building set criteria for alternative modernisation measures. Experts using pairwise comparisons determined significance values of indicators.

A decision tree helped to develop alternative combinations of modernisation measures (Figure 3). This model identified possible isolation combinations for the plinth, walls and roof. The combinations can use several variants. The method for the multi-criteria assessment of alternatives was elected applying the SyMAD-3 method that allowed selecting the most effective variant from all available alternatives. The application of decision tree principles resulted in many alternative combinations; thus, the priority list of alternatives was used. Analysis of energy need for alternative combined solutions used in modernisation impacts the overall energy consumption of the building. Therefore, the best option policymakers could select only by using MCDM method that satisfies values of performance indicators such as price, energy consumption, and others.

\section{Definition and significance of indicators}

Comparison using the pairwise method helped to determine the magnitude of indicator performance. An optimisation problem was used to determine numerical values for subjective significances of indicators $q_{j}(j=\overline{1, n})$ :

$$
\min \left\{\sum_{i=1}^{n} \sum_{j=1}^{n}\left(b_{i j} \bar{q}_{j}-\bar{q}_{i}\right)^{2}\right\},
$$

where, $b_{i j}$ - pairwise comparison of indicators $R_{i}$ and $R_{j}$ made by experts $i, j=\overline{1, n}$. This indicator refers to the significance ratio of expert estimates of the $i$ and $j$ indicators. Additional condition:

$$
\sum_{i=1}^{n} \bar{q}_{i}=1
$$

Pairwise comparison matrixes helped to systemise the selected information. Policymakers assessed significances of each structural part of the building. They listed indicators following their importance. Table 4 shows the indicators selected for the modernisation of a public building. 
Table 4. Performance indicators identified during the analysis of alternative modernisation measures

\begin{tabular}{|c|l|c|}
\hline No. & \multicolumn{1}{|c|}{ Indicators } & Measurement units \\
\hline 1 & Thermal transmittance & $\mathrm{W} / \mathrm{m}^{2} \mathrm{~K}$ \\
\hline 2 & Price of the modernisation & $\mathrm{EUR}$ \\
\hline 3 & Forecasted lifetime of the measure & $\mathrm{yrs}$ \\
\hline 4 & Possible construction works despite the seasonality & $\mathrm{points}$ \\
\hline 5 & Annual savings & $\mathrm{kWh} / \mathrm{m}^{2} / \mathrm{yrs}$ \\
\hline 6 & Simple payback period & $\mathrm{yrs}$ \\
\hline 7 & Thickness of the structure & $\mathrm{mm}$ \\
\hline
\end{tabular}

Note: ${ }^{\star}$ Only applicable to the plinth, external walls and the roof.

\section{SyMAD-3 - a method to synthesise modernisation decisions for building structures}

In this case, the decision-making process used the method for the synthesis of multiple attribute decisions SyMAD-3 (Simanaviciene et al., 2012; Simanaviciene \& Ustinovichius, 2012). Problem solvers the reliability of the solution improve using three MCDM methods based on quantitative measurements. The structure of the decision analysis was presented as a multistage decision tree (Figure 3). This analysis tree diagram was described using the following principles:

- the set of decision analysis stages $K=\{k\},(k=1,2, \ldots, c), k$ - the stage number, $c$ - the number of stages;

- the number of decision-tree nodes in each Stage $-m_{k}(k=1,2, \ldots, c)$ was determined considering the number of decision tables;

- the number of modelled decision tree branches that connect the root node with a leaf node: $z=m_{c}$, where $m_{c}$ - the number of nodes of the last decision tree stage. The total amount of decision tree branches represents all combinations of calculated alternatives.

Having the decision analysis model and required data available, the rational decision-making process could start, i.e., selecting a respective algorithm to rank alternatives by their rationality - SyMAD-3. The algorithm of the method comprised of two stages.

The first decision phase was meant to formulate the problem, prepare the data and make the initial assessment of alternatives. This Stage had six steps:

1. They were defining decision stages, establishing a performance indicator system for each stage of the decision tree $K=\{k\},(k=1,2 \ldots, c)$. Making tables of decisions for each decision stage, where $m_{k}-$ the number of decision tables in the $k$ stage. Decision matrixes were developed using these tables of data:

$$
X_{t}=\left[x_{i j}^{t}\right],\left(t=\overline{1, m_{k}} i=\overline{1, a_{t}}, j=\overline{1, n_{k}}\right),
$$

where, $t$ - the number of the decision table, $a_{t}$ - the number of alternatives of the $t$ decision table, $n_{k}$ - the number of performance indicators of the $k$ stage. 
2. Populating the expert pairwise comparison matrixes used to determine the significance of performance indicators.

$$
E=\{p\}, p=1,2, \ldots, e_{p},
$$

where, $E$ - the set of experts, $p$ - the expert number, $e_{p}-$ the number of experts.

3. Determining the compatibility of pairwise comparison matrixes. For this purpose, each matrix as taken to estimate its degree of compatibility $S$ :

$$
S=\frac{S_{I}}{S_{A}},
$$

where, $S_{I}$ - the matrix compatibility index, $S_{A}-$ the mean random index. If $S<0.1$, the matrix was sufficiently compatible and could be used to determine the subjective significance; otherwise, the matrix data were eliminated from further calculations (Saaty, 1994).

4. Policymakers determine the significances of the $k$ stage indicators. The expert-filled matrixes for indicator pairwise comparison and the method of least squares were used to estimate the subjective significances of indicators $\bar{q}_{k j},(j=\overline{1, n}, k=\overline{1, c})$. Based on the information regarding the subjective significances of indicators, expert opinions regarding indicator significances were examined for compatibility, estimating the concordance coefficient. If the compatibility of expert opinions on the indicator significances was sufficient, integrated significances of indicators $q_{k j}^{*},\left(j=\overline{1, n}_{k}, k=\overline{1, c}\right)$ were estimated next. If the compatibility of expert opinions is insufficient, the composition of the expert group needs reconsidering. The estimation of indicators was repeated, using the data of the renewed expert group.

5. The earlier-mentioned decision matrixes $X_{t}=\left[x_{i j}^{t}\right],\left(t=\overline{1, m_{k}}, i=\overline{1, a_{t}}, j=\overline{1, n_{k}}\right)$ and integrated significances of indicators $q_{k j}^{*},\left(j=\overline{1, n}_{k}, k=\overline{1, c}\right)$ were used to determine alternative rationality applying three methods: TOPSIS, COPRAS, SAW.

6. Following the estimations based on all three methods, the results were supplied in the form of relative significance criteria according to TOPSIS, SAW and COPRAS methods, no summed:

$$
\left(A_{k}^{i}[\text { TOPSIS, SAW }, \text { COPRAS }]\right)=\left(R_{k T}^{i}, R_{k S}^{i}, R_{k C}^{i}\right), k=\overline{1, c}, i=\overline{1, m_{k}},
$$

The second decision stage was intended to develop alternative combinations and assess their rationality. The decision tree model and the rationality assessment results for alternatives received during the first decision stage, which were described in decision tables $A_{k}$, were used to make alternative combinations

$$
B_{s},(s=\overline{1, z}) .
$$

The second Stage comprised of three stages:

1. Data of alternative combinations were supplied in the vector form:

$$
B_{s}=\left\{\left(R_{1, T}^{i}, R_{1, S}^{i}, R_{1, C}^{i}\right), \ldots\left(R_{c, T}^{i}, R_{c, S}^{i}, R_{c, C}^{i}\right)\right\}, i=\overline{1, m_{k}}, k=\overline{1, c} .
$$


2. Decision tables were filled with resulting alternatives; later, this data was used for further calculations.

3. Alternative combinations were assessed (TOPSIS, SAW and COPRAS). The decision matrix was created:

$$
Y=\left[B_{s}\right]=\left[y_{s l}\right], s=\overline{1, z}, l=\overline{1, k \times m t},
$$

where, $m_{t}$ - the number of methods used, $k$ - the stage number, $(k=1,2, \ldots, \mathrm{c})$. In this case, $s$ - the number of rows in the matrix $Y, l-$ the number of columns in the matrix $Y$.

$$
\left(y_{s l}\right)=\left(R_{i j}^{k_{l}}\right), k=\overline{1, c}, i=\overline{1, m_{k}}, l=\overline{1, k \times m t} .
$$

The set was created from indicators required for the assessment of alternatives provided in the matrix $Y: R=\left\{R_{1}\right\},(l=1,2, \ldots, k \times m t)$. The optimal indicators value was the maximum as well as their significances; neither subjective nor objective factors had any impact on them. Indicator significances had to satisfy the condition:

$$
\sum_{l=1}^{k x m t} w l=1,
$$

where, $k$ - the number of stages, $m t$ - the number of methods.

Following the assessments of alternative combinations with the help of methods named above, rationality estimates and alternative combination ranks (as per importance) were supplied in the form of a table in respect of each method (Table 5). The presented method can be used for various multistage, multi-attribute decision problems when information regarding alternatives is supplied in the quantitative form (Figure 4).

In the analysed case, the SyMAD-3 method was used for the decision analysis and synthesis regarding structural partitions. This method combines estimations of the Complex Proportional Assessment (COPRAS) (Zavadskas et al., 1994), the TOPSIS (Hwang \& Yoon, 1981) and the SAW (MacCrimmon, 1968) methods.

COPRAS (Zavadskas et al., 2004; Kaklauskas et al., 2006) method addresses priorities and significances that are directly dependent on the indicator system that describes alternatives. Experts estimate initial significances. Thus, stakeholders (the property manager or the client, and others) can adjust the information considering the existing situation and set aims. Therefore, these results for the assessment of alternatives provide initial data jointly supplied

Table 5. Decision table of alternative combinations

\begin{tabular}{|c|c|c|c|c|c|c|c|}
\hline Stages & \multicolumn{3}{|c|}{ First Stage } & \multicolumn{3}{c|}{$c$ Stage } \\
\hline $\begin{array}{l}\text { Indicators } \\
\text { Alternatives }\end{array}$ & $\mathrm{R}_{[1]}$ & $\mathrm{R}_{[2]}$ & $\mathrm{R}_{[3]}$ & $\ldots$ & $\mathrm{R}_{[7]}$ & $\mathrm{R}_{[8]}$ & $\mathrm{R}_{[9]}$ \\
\hline $\mathrm{B}_{1}$ & $\mathrm{R}_{1, \mathrm{~T}}^{1_{1}}$ & $\mathrm{R}_{1, \mathrm{~S}}^{1_{1}}$ & $\mathrm{R}_{1, \mathrm{C}}^{1_{1}}$ & $\ldots$ & $\mathrm{R}_{\mathrm{c}, \mathrm{T}}^{1_{\mathrm{t}}}$ & $\mathrm{R}_{c, \mathrm{~S}}^{1_{\mathrm{t}}}$ & $\mathrm{R}_{c, \mathrm{C}}^{\mathrm{t}_{\mathrm{t}}}$ \\
\hline \multicolumn{7}{|c|}{$\vdots$} \\
\hline $\mathrm{B}_{\mathrm{z}}$ & $\mathrm{R}_{1, \mathrm{~T}}^{\mathrm{a}_{\mathrm{t}}}$ & $\mathrm{R}_{1, \mathrm{~S}}^{\mathrm{a}_{\mathrm{t}}}$ & $\mathrm{R}_{1, \mathrm{C}}^{\mathrm{a}_{\mathrm{t}}}$ & $\ldots$ & $\mathrm{R}_{\mathrm{c}, \mathrm{T}}^{\mathrm{a}_{\mathrm{t}}}$ & $\mathrm{R}_{c, \mathrm{~S}}^{\mathrm{a}_{\mathrm{t}}}$ & $\mathrm{R}_{\mathrm{c}, \mathrm{C}}^{\mathrm{a}_{\mathrm{t}}}$ \\
\hline $\operatorname{Min} / \max$ & Max & Max & Max & $\ldots$ & $\operatorname{Max}$ & Max & Max \\
\hline
\end{tabular}




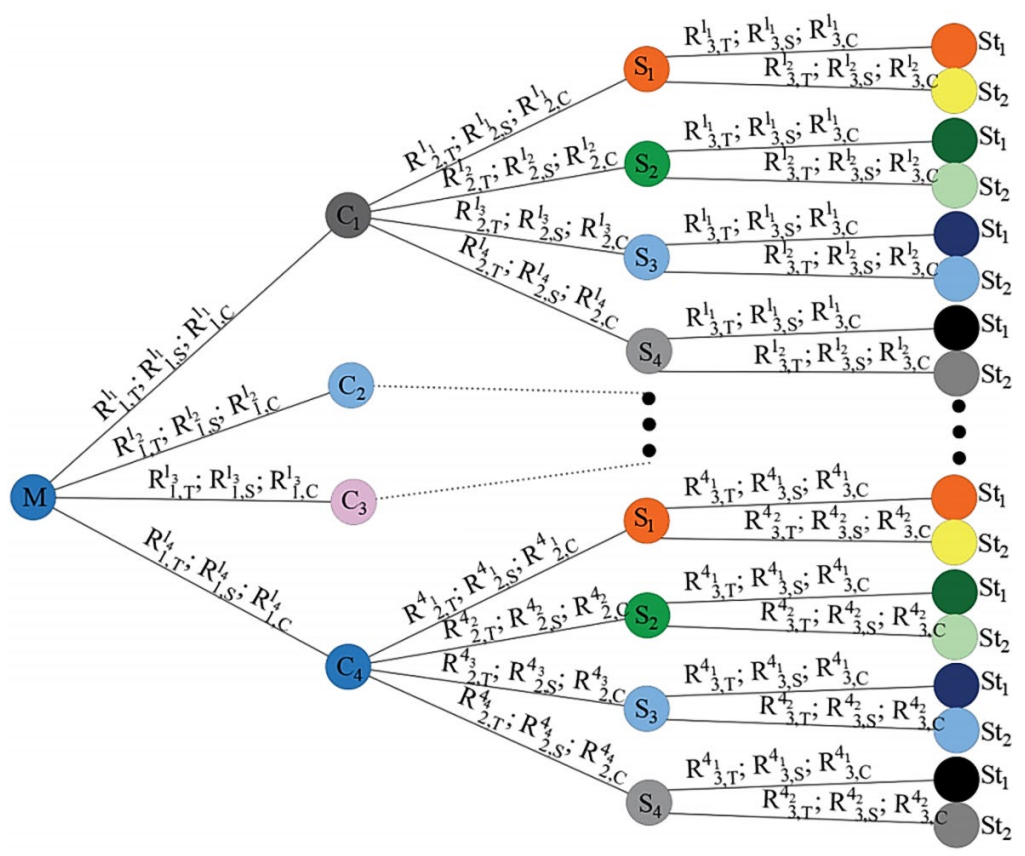

Figure 3. Fragment of the decision tree for the selection of modernisation measures' alternative combinations. The tree uses data from Table 5. There: $\mathrm{M}-$ modernisation option, $\mathrm{C}_{\mathrm{n}}$ - plinth option, $\mathrm{S}_{\mathrm{n}}-$ wall option, $\mathrm{St}_{\mathrm{n}}-$ roof option

by experts and stakeholders. This method determines the priority using the equation:

$$
Q_{i}=S_{+i}+\frac{S_{-\min } \sum_{i=1}^{m} S_{-i}}{S_{-i} \sum_{i=1}^{m} \frac{S_{-\min }}{S_{-i}}}, i=\overline{1, m} .
$$

where, $S_{+i}$ describes the positive and $S_{-i}$ defines the negative characteristics determining the relative significance of compared variants. The project effectiveness is expressed by the value $Q_{i}$ : the larger is the value, the higher is the priority.

TOPSIS method defines the setting of variant rationality. This method is characterised as the least distance of the optimal alternative from the ideal result and the maximum distance from the worst solution (Hwang \& Yoon, 1981). This type of approach is called the Technique for Order Preference by Similarity to Ideal Solution - TOPSIS. The relative distance of each $i$ variant to the ideal is determined using the following equation:

$$
K_{i}=\frac{L_{i}^{-}}{L_{i}^{+}+L_{i}^{-}}, i=\overline{1, m}, K_{i} \in[0 ; 1],
$$

where, $L_{i}^{+}$- the distance between the compared $i$ and the ideally best variant; $L_{i}^{-}-$the distance between the compared $i$ and negatively ideal variant. The closer is the value $L_{i}$ to one, the closer is the $i$ variant to $a+$, i.e., the rational variant will be the one with the greatest value of $L_{i}$.

The rationality of variants is determined using the Simple Additive Weighting (SAW) method (MacCrimmon, 1968). 


\section{Energy performance analysis of the investigated public building and the selection of the modernisation solution}

A building in need of modernisation was selected to validate this model. The administrative building was the Switching Control Centre, located in Radviliškis, Lithuania. The overall area of the building amounted to $1455.73 \mathrm{~m}^{2}$. The planned works included the redesign of floor arrangement, remodelling, the improvement of energy performance indicators, external wall insulation, replacement of HVAC (heating, ventilation, and air conditioning) systems. The analysed four-floor building was constructed from calcium silicate bricks, non-insulated. The interior was outdated and dilapidated. The HVAC systems did not correspond to requirements. The building last time was repaired in 1998.

As the building was old, practically no information was available about the materials used for its construction; consequently, the inventory (audit) of the building had to be made to determine its real condition. Data of existing buildings can be collected using laser scanners with thermographic cameras. This technology allows for an automated collection and processing of data, determining thermal bridges, structural fractures, HVAC systems. This building was analysed using a combined method, i.e. the assessment in situ and using a 3D photogrammetric model (made from photographs). The model for the project was developed from 1000 photos made using a drone. The existing situation of the building was analysed as well as the energy loss through plinths, roof and external walls (Figure 4). The analysis of the structure determined its physical depreciation before the modernisation works.

Determining key indicators for structural partitions and engineering systems (energy simulation). Calculations were made to assess the thermal conductivity coefficient $U$ (W/ $\left.\left(\mathrm{m}^{2} \cdot \mathrm{K}\right)\right)$ for plinth, roof and external wall structures.

Analogically, estimations were made for thermal transmittances of existing external walls $\left(1.383\left(\mathrm{~W} /\left(\mathrm{m}^{2} \cdot \mathrm{K}\right)\right)\right.$ and the existing roof $\left(1.033\left(\mathrm{~W} /\left(\mathrm{m}^{2} \cdot \mathrm{K}\right)\right)\right.$.

In the beginning, the photogrammetric model of the building, as well as interior inventory plans, were used to determine general building parameters. The designed photogrammetric model made calculations easier and helped to achieve precise assessments of external walls, windows and the roof.

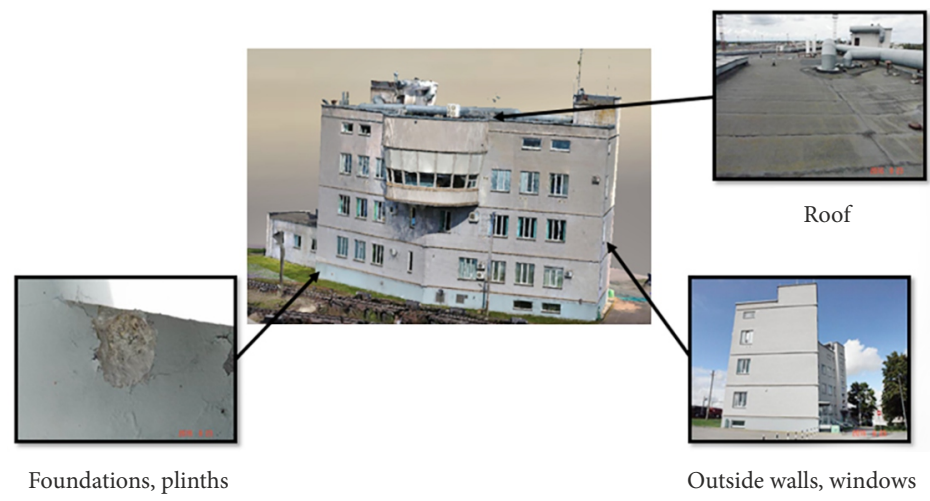

Figure 4. Analysis of the photogrammetric model 
Making energy simulations of building elements. It was established that the designed building was intended for public purposes. Determining energy efficiency class of buildings (their parts), critical values of structural partitions have values $\mathbf{B}$ of thermal transmittances $U(C, B)\left(\mathrm{W} /\left(\mathrm{m}^{2 \star} \mathrm{K}\right)\right)$ for structural partitions. Variation intervals for crucial indicators of structural partitions and engineering systems were based on rules presented in Table 3. Variation intervals that correspond to the set energy efficiency class were found for structures and engineering systems (Table 6). This matrix was formed from the decision matrix used to determine thermal transmittances of the most effective structural partitions and efficiencies of engineering systems.

Determining key building elements with the most effective indicators (structures and systems). Based on Table 6, a decision matrix was made. The SAW method was used to determine variant priorities. Table 7 provides the best variant.

Defining the method of modernisation. Following simple estimations of thermal parameters of the building, differences were found between thermal parameters of the existing structures and those to be achieved (Table 8). Windows were estimated separately for each selected structure variant.

Table 6. Critical indicator values (affecting the energy efficiency class) of structural partitions and engineering systems, determined based on variation intervals

\begin{tabular}{|c|c|c|c|c|c|c|c|c|c|c|c|}
\hline \multirow[b]{2}{*}{ No. } & \multicolumn{5}{|c|}{$\begin{array}{l}\text { Indicators (thermal } \\
\text { transmittances) }\end{array}$} & \multicolumn{3}{|c|}{$\begin{array}{l}\text { Definitions of engineering } \\
\text { systems }\end{array}$} & \multicolumn{3}{|c|}{ Energy consumption } \\
\hline & $\begin{array}{l}\text { प्ष } \\
\stackrel{0}{\circ}\end{array}$ & 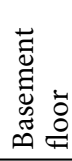 & 声 & $\frac{\infty}{\bar{m}}$ & 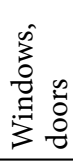 & 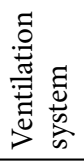 & 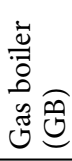 & 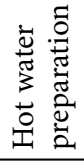 & 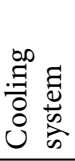 & 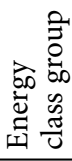 & 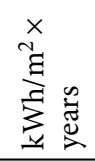 \\
\hline 1 & 0.15 & 0.25 & 0.25 & 0.2 & 1.2 & 0.7 & yes & GB & $\mathrm{AC}$ & B & 184.23 \\
\hline 2 & 0.20 & 0.25 & 0.25 & 0.2 & 1.2 & 0.7 & yes & GB & $\mathrm{AC}$ & B & 186.3 \\
\hline 3 & 0.25 & 0.25 & 0.25 & 0.2 & 1.2 & 0.7 & yes & GB & $\mathrm{AC}$ & B & 188.4 \\
\hline \\
\hline 213 & 0.25 & 0.25 & 0.25 & 0.2 & 2 & 0.9 & yes & GB & $\mathrm{AC}$ & B & 201.71 \\
\hline 214 & 0.15 & 0.3 & 0.25 & 0.2 & 2 & 0.9 & yes & GB & $\mathrm{AC}$ & B & 198.26 \\
\hline \\
\hline 234 & 0.25 & 0.3 & 0.25 & 0.3 & 2 & 0.9 & yes & GB & $\mathrm{AC}$ & B & 215.5 \\
\hline
\end{tabular}

Table 7. Indicators of the most effective variant

\begin{tabular}{|c|c|c|c|c|c|c|c|}
\hline \multirow[b]{2}{*}{. } & \multicolumn{6}{|c|}{ Indicators (thermal transmittances) } & \multirow[b]{2}{*}{$\begin{array}{l}3 \\
0 \\
0 \\
0 \\
0 \\
0 \\
0 \\
0 \\
0\end{array}$} \\
\hline & $\begin{array}{l}\text { प्ठ } \\
\stackrel{0}{0}\end{array}$ & 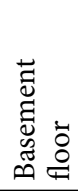 & $\frac{n}{7}$ & 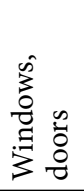 & 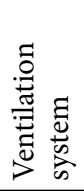 & 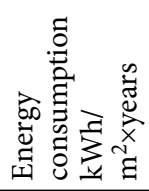 & \\
\hline 100 & 0.25 & 0.35 & 0.3 & 1.2 & 0.9 & 196.6 & 1 \\
\hline
\end{tabular}


Table 8. Determining structures and engineering systems with missing characteristics for variant No. 100

\begin{tabular}{|l|c|c|c|c|c|c|}
\hline \multirow{2}{*}{$\begin{array}{c}\text { Variation } \\
\text { interval }\end{array}$} & \multicolumn{5}{|c|}{ Indicators } \\
\cline { 2 - 7 } & Roof & $\begin{array}{c}\text { Basement } \\
\text { floor }\end{array}$ & Walls & $\begin{array}{c}\text { Windows, } \\
\text { doors }\end{array}$ & $\begin{array}{c}\text { Ventilation } \\
\text { system }\end{array}$ & $\begin{array}{c}\text { Energy consumption } \\
\mathrm{kWh} / \mathrm{m}^{2} \times \text { years }\end{array}$ \\
\hline No. 100 & 0.15 & 0.3 & 0.3 & 1.2 & 0.8 & 192.6 \\
\hline Existing & 1.03 & 1.54 & 1.38 & 2.5 & 0 & 413.6 \\
\hline Difference & 0.88 & 1.24 & 1.08 & 1.3 & 0.8 & 221.0 \\
\hline
\end{tabular}

Windows: Variant 1 - thermal transmittance $U-1.2 \mathrm{~W} / \mathrm{m}^{2} \mathrm{~K}$; the price of the works - EUR 60743. Annual savings $-29.63 \mathrm{kWh} / \mathrm{m}^{2} / \mathrm{yrs}$. Simple payback time -20 years. Based on the initial data, further calculations were made to determine the best modernisation alternative.

Alternatives were selected to find the solution for the modernisation problem of the building in Radviliškis, among which the best modernisation alternative was found. The following elements of the building were analysed: the plinth, external walls, and the roof. Thermal conductivity indicators $U$ (variant 100) of the structure to be achieved were as follow:

- For walls: $U=0.3 \mathrm{~W} /\left(\mathrm{m}^{2} \mathrm{~K}\right)$;

- For the roof: $U=0.15 \mathrm{~W} /\left(\mathrm{m}^{2} \mathrm{~K}\right)$;

- For the plinth: $U=0.25 \mathrm{~W} /\left(\mathrm{m}^{2} \mathrm{~K}\right)$;

- For windows $U=1.2 \mathrm{~W} /\left(\mathrm{m}^{2} \mathrm{~K}\right)$;

Table 9 presents variants, with the help of which the required effect could be achieved.

Table 9. Modernisation variants for critical structures

\begin{tabular}{|c|c|c|c|}
\hline No. & Plinth alternatives & Wall alternatives & Roof alternatives \\
\hline 1 & $\begin{array}{l}\text { Expanded polystyrene EPS } \\
100 \text { of the missing required } \\
\text { thickness (according to Table } \\
8 \text { ) is used to insulate the } \\
\text { existing reinforced concrete } \\
\text { blocks, having the thickness } \\
\text { of } 400 \mathrm{~mm} \text {, insulating to the } \\
\text { depth of } 800 \mathrm{~mm} \text {; tiles are } \\
\text { used for finishing. Plinth } \\
\text { protection is installed around } \\
\text { the building }\end{array}$ & $\begin{array}{l}\text { The exiting calcium silicate } \\
\text { brick wall, having the } \\
\text { thickness of } \mathrm{d} 1=510 \mathrm{~mm} \text {, } \\
\text { is insulated using the } \\
\text { expanded polystyrene EPS } \\
70 \mathrm{~F} \text { of the missing required } \\
\text { thickness (according to } \\
\text { Table 8). The polystyrene } \\
\text { is attached using glue. } \\
\text { Reinforcement mesh is } \\
\text { placed and covered in thin } \\
\text { coat plaster }\end{array}$ & $\begin{array}{l}\text { Old roll roofing is removed, and } \\
\text { thermal insulation materials are } \\
\text { fixed. The under layer of the } \\
\text { expanded polystyrene EPS } 80 \text { of } \\
\text { the missing required thickness } \\
\text { (according to Table 8) is placed. } \\
\text { Hard rock wool slab ROS } 30 \text {, } \\
\text { having a thickness of } 30 \mathrm{~mm} \text {, } \\
\text { is placed followed by double- } \\
\text { layer torch-on waterproofing. } \\
\text { Parapet flashing is placed, and } \\
\text { ventilation ducts are insulated }\end{array}$ \\
\hline 2 & $\begin{array}{l}\text { Expanded polystyrene EPS } \\
100 \text { of the missing required } \\
\text { thickness (according to Table } \\
8 \text { ) is used to insulate the } \\
\text { existing reinforced concrete } \\
\text { blocks, having the thickness } \\
\text { of } 400 \mathrm{~mm} \text {, insulating to } \\
\text { the depth of } 800 \mathrm{~mm} \text {; the } \\
\text { damp proof course is used } \\
\text { for covering. New plinth } \\
\text { protection is installed around } \\
\text { the building }\end{array}$ & $\begin{array}{l}\text { The exiting calcium silicate } \\
\text { brick wall, having the } \\
\text { thickness of } \mathrm{d} 1=510 \mathrm{~mm} \text {, } \\
\text { is insulated using the } \\
\text { expanded polystyrene } \\
\text { EPS 70F (Neopor) of the } \\
\text { missing required thickness } \\
\text { (according to Table } 8 \text { ). The } \\
\text { polystyrene is attached } \\
\text { using glue. Reinforcement } \\
\text { mesh is placed and covered } \\
\text { in thin coat plaster }\end{array}$ & $\begin{array}{l}\text { Old roll roofing is removed, and } \\
\text { old thermal insulation materials } \\
\text { are fixed. The under layer of the } \\
\text { insulating rock wool ROS } 30 \text { of } \\
\text { the missing required thickness } \\
\text { (according to Table 8) is placed. } \\
\text { Hard rock wool slab ROS } 30 \text {, } \\
\text { having a thickness of } 30 \mathrm{~mm} \text {, } \\
\text { is placed followed by double- } \\
\text { layer torch-on waterproofing. } \\
\text { Parapet flashing is placed, and } \\
\text { ventilation ducts are insulated }\end{array}$ \\
\hline
\end{tabular}


End of Table 9

\begin{tabular}{|c|c|c|c|}
\hline No. & Plinth alternatives & Wall alternatives & Roof alternatives \\
\hline 3 & $\begin{array}{l}\text { Expanded polystyrene EPS } \\
100 \text { of the missing required } \\
\text { thickness (according to Table } \\
8 \text { ) is used to insulate the } \\
\text { existing reinforced concrete } \\
\text { blocks, having the thickness } \\
\text { of } 400 \mathrm{~mm} \text {, insulating to the } \\
\text { ground depth of } 800 \mathrm{~mm} \text {. } \\
\text { The polystyrene above the } \\
\text { ground is covered using a } \\
\text { finishing panel, and below } \\
\text { the ground - a drainage } \\
\text { membrane. New plinth } \\
\text { protection is installed around } \\
\text { the building }\end{array}$ & $\begin{array}{l}\text { The exiting wall of calcium } \\
\text { silicate bricks, with the } \\
\text { thickness of } \mathrm{d} 1=510 \mathrm{~mm} \text {, } \\
\text { is insulated using rock wool } \\
\text { of the missing required } \\
\text { thickness (according to } \\
\text { Table } 8 \text { ), windproof rock } \\
\text { wool of the thickness } \mathrm{d} 3= \\
25 \mathrm{~mm} \text {, then leaving a } 20 \\
\text { mm ventilation air gap and } \\
\text { using a } 10 \mathrm{~mm} \text { façade panel } \\
\text { (HPL panel) }\end{array}$ & \\
\hline 4 & $\begin{array}{l}\text { Expanded polystyrene EPS } \\
100 \text { of the missing required } \\
\text { thickness (according to Table } \\
8 \text { ) is used to insulate the } \\
\text { existing reinforced concrete } \\
\text { blocks, having the thickness } \\
\text { of } 400 \mathrm{~mm} \text {, insulating to } \\
\text { the depth of } 800 \mathrm{~mm} \text {. The } \\
\text { polystyrene above the ground } \\
\text { is covered in thin coat plaster, } \\
\text { and below the ground - a } \\
\text { drainage membrane. New } \\
\text { plinth protection is installed } \\
\text { around the building }\end{array}$ & $\begin{array}{l}\text { The exiting calcium silicate } \\
\text { brick wall, having the } \\
\text { thickness of } \mathrm{d} 1=510 \mathrm{~mm} \text {, } \\
\text { is insulated using rock wool } \\
\text { of the missing required } \\
\text { thickness (according to } \\
\text { Table } 8 \text { ). The rock wool is } \\
\text { attached using glue and } \\
\text { pins. Reinforcement mesh is } \\
\text { placed and covered in thin } \\
\text { coat plaster }\end{array}$ & \\
\hline
\end{tabular}

Analysis of structure modernisation variants. The analysis of structure modernisation variants was performed for the best energy simulation variant No. 100. The definition of structural variants with estimated modernisation indicators are given in Tables 10-12.

Table 10. Variants for the plinth modernisation

\begin{tabular}{|c|c|c|c|c|c|c|c|}
\hline \multirow[b]{2}{*}{$\begin{array}{l}\text { Alternatives for the } \\
\text { plinth modernisation }\end{array}$} & \multicolumn{7}{|c|}{ Indicators for the plinth modernisation } \\
\hline & 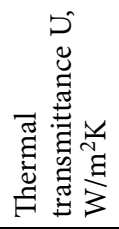 & 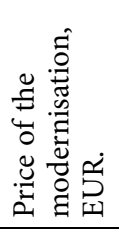 & 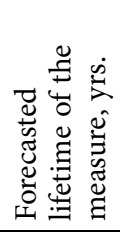 & 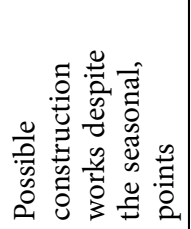 & 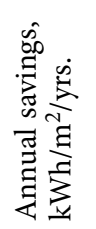 & 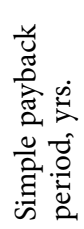 & 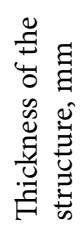 \\
\hline 1 & 2 & 3 & 4 & 5 & 6 & 7 & 8 \\
\hline Plinth 1 & 0.25 & 43354 & 30 & 2 & 2.91 & 144 & 610 \\
\hline Plinth 2 & 0.25 & 33694 & 25 & 2 & 2.91 & 112 & 610 \\
\hline Plinth 3 & 0.25 & 43876 & 27 & 6 & 2.91 & 146 & 610 \\
\hline Plinth 4 & 0.25 & 34209 & 25 & 2 & 2.91 & 114 & 610 \\
\hline Minimised/maximised & $\min$ & $\min$ & $\max$ & $\max$ & $\max$ & $\min$ & $\max$ \\
\hline Significance $q$ & 0.121 & 0.254 & 0.151 & 0.046 & 0.173 & 0.175 & 0.080 \\
\hline
\end{tabular}


Table 11. Variants for the modernisation of walls

\begin{tabular}{|c|c|c|c|c|c|c|c|}
\hline \multirow[b]{2}{*}{$\begin{array}{l}\text { Alternatives } \\
\text { for the modernisation } \\
\text { of walls }\end{array}$} & \multicolumn{7}{|c|}{ Indicators for the modernisation of walls } \\
\hline & 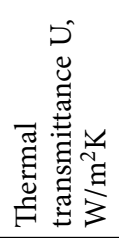 & 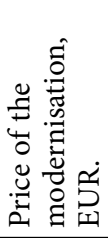 & 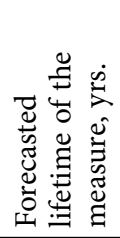 & 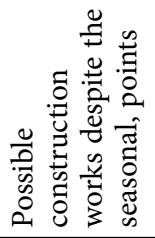 & 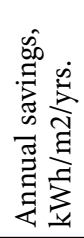 & 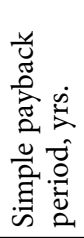 & 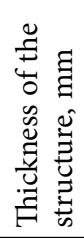 \\
\hline Wall 1 & 0.3 & 81377 & 25 & 3 & 118 & 7 & 600 \\
\hline Wall 2 & 0.3 & 82253 & 26 & 4 & 118 & 7 & 590 \\
\hline Wall 3 & 0.3 & 121754 & 27 & 6 & 118 & 10 & 635 \\
\hline Wall 4 & 0.3 & 84284 & 25 & 3 & 118 & 7 & 600 \\
\hline Minimised/maximised & $\min$ & $\min$ & $\max$ & $\max$ & $\max$ & $\min$ & $\max$ \\
\hline Significance $q$ & 0.140 & 0.245 & 0.136 & 0.047 & 0.162 & 0.172 & 0.098 \\
\hline
\end{tabular}

Table 12. Variants for the roof modernisation

\begin{tabular}{|c|c|c|c|c|c|c|c|}
\hline \multirow[b]{2}{*}{$\begin{array}{l}\text { Alternatives for } \\
\text { the roof modernisation }\end{array}$} & \multicolumn{7}{|c|}{ Indicators for the roof modernisation } \\
\hline & 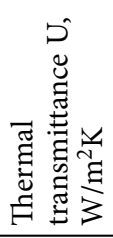 & 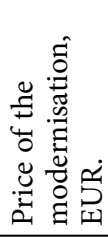 & 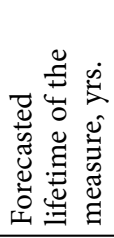 & 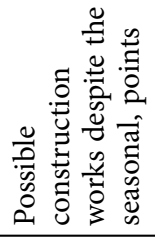 & 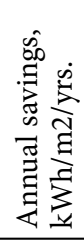 & 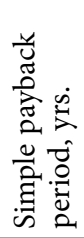 & 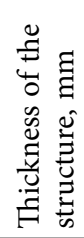 \\
\hline Roof 1 & 0.15 & 40539 & 25 & 6 & 35.51 & 11 & 460 \\
\hline Roof 2 & 0.15 & 46803 & 25 & 4 & 35.51 & 13 & 460 \\
\hline Minimised/maximised & $\min$ & $\min$ & $\max$ & $\max$ & $\max$ & $\min$ & $\max$ \\
\hline Significance $q$ & 0.136 & 0.260 & 0.132 & 0.049 & 0.155 & 0.216 & 0.052 \\
\hline
\end{tabular}

Windows: variant 1 with the thermal transmittance of $\mathrm{U}-1.2 \mathrm{~W} / \mathrm{m}^{2} \mathrm{~K}$; and the price of works of 60743 EUR. Annual savings would amount to $29.63 \mathrm{kWh} / \mathrm{m}^{2} / \mathrm{yrs}$. The simple payback time - 20 years.

A separate assessment was made for the plinth (Table 13), walls (Table 14) and the roof (Table 15).

Table 13. Results of the plinth modernisation variants using three MCDM (TOPSIS (MT $)$, SAW $\left(\mathrm{MT}_{2}\right)$, and COPRAS $\left.\left(\mathrm{MT}_{3}\right)\right)$ methods

\begin{tabular}{|c|c|c|c|}
\hline Mlternative & $\mathrm{MT}_{1}$ & $\mathrm{MT}_{2}$ & $\mathrm{MT}_{3}$ \\
\hline Plinth 1 & 0.235 & 0.875 & 0.113 \\
\hline Plinth 2 & 0.572 & 0.944 & 0.106 \\
\hline Plinth 3 & 0.398 & 0.887 & 0.124 \\
\hline Plinth 4 & 0.558 & 0.939 & 0.106 \\
\hline
\end{tabular}


Table 14. Results of the modernisation variants for walls using three MCDM methods

\begin{tabular}{|c|c|c|c|}
\hline Alternative & $\mathrm{MT}_{1}$ & $\mathrm{MT}_{2}$ & $\mathrm{MT}_{3}$ \\
\hline Wall 1 & 0.777 & 0.962 & 0.106 \\
\hline Wall 2 & 0.835 & 0.968 & 0.110 \\
\hline Wall 3 & 0.224 & 0.868 & 0.119 \\
\hline Wall 4 & 0.764 & 0.953 & 0.106 \\
\hline
\end{tabular}

Table 15. Results of the roof modernisation variants using three MCDM methods

\begin{tabular}{|c|c|c|c|}
\hline Alternative & $\mathrm{MT}_{1}$ & $\mathrm{MT}_{2}$ & $\mathrm{MT}_{3}$ \\
\hline Roof 1 & 1 & 1 & 0.199 \\
\hline Roof 2 & 0 & 0.914 & 0.189 \\
\hline
\end{tabular}

Following the assessment of separate building alternative elements (the plinth, walls and the roof), the evaluation focused on all possible combinations based on the decision tree for modernisation (Figure 4). Four plinth variants, four wall variants and two roof variants were selected to make the modernisation decision. The modifications resulted in 32 options to undertake modernisation assessment processes. The assessment was made using SyMAD-3. Tables 16 and 17 present the received alternative. Later, ranks of alternative combinations were determined based on results received using three before mentioned methods (Table 18).

Table 16. Alternative combinations made from estimates received using three MCDM methods

\begin{tabular}{|c|c|c|c|c|c|c|c|c|c|}
\hline & \multicolumn{3}{|c|}{ Plinth } & \multicolumn{3}{|c|}{ Wall } & \multicolumn{3}{|c|}{ Roof } \\
\hline & $\mathrm{MT}_{1}$ & $\mathrm{MT}_{2}$ & $\mathrm{MT}_{3}$ & $\mathrm{MT}_{1}$ & $\mathrm{MT}_{2}$ & $\mathrm{MT}_{3}$ & $\mathrm{MT}_{1}$ & $\mathrm{MT}_{2}$ & $\mathrm{MT}_{3}$ \\
\hline B1 & 0.235 & 0.874 & 0.113 & 0.777 & 0.961 & 0.106 & 1 & 1 & 0.199 \\
\hline B2 & 0.235 & 0.874 & 0.113 & 0.777 & 0.961 & 0.106 & 0 & 0.915 & 0.189 \\
\hline \\
\hline B11 & 0.572 & 0.945 & 0.106 & 0.835 & 0.969 & 0.110 & 1 & 1 & 0.199 \\
\hline B12 & 0.572 & 0.945 & 0.106 & 0.835 & 0.969 & 0.110 & 0 & 0.915 & 0.189 \\
\hline \multicolumn{10}{|c|}{$\vdots$} \\
\hline B23 & 0.398 & 0.886 & 0.125 & 0.764 & 0.952 & 0.106 & 1 & 1 & 0.199 \\
\hline B24 & 0.398 & 0.886 & 0.125 & 0.764 & 0.952 & 0.106 & 0 & 0.915 & 0.189 \\
\hline \multicolumn{10}{|c|}{$\vdots$} \\
\hline B32 & 0.558 & 0.938 & 0.106 & 0.764 & 0.952 & 0.106 & 0 & 0.915 & 0.189 \\
\hline
\end{tabular}


Table 17. Results of alternative combinations received using three MCDM methods

\begin{tabular}{|c|c|c|c|}
\hline $\begin{array}{c}\text { Alternative } \\
\text { combinations }\end{array}$ & $\mathrm{MT}_{1}$ & $\mathrm{MT}_{2}$ & $\mathrm{MT}_{3}$ \\
\hline B1 & 0.683 & 0.252 & 0.009 \\
\hline B2 & 0.333 & 0.216 & 0.007 \\
\hline \multicolumn{5}{|c|}{$\vdots$} \\
\hline B11 & 0.910 & 0.274 & 0.010 \\
\hline B12 & 0.446 & 0.239 & 0.008 \\
\hline B24 & 0.371 & 0.228 & 0.008 \\
\hline B25 & 0.891 & 0.270 & 0.010 \\
\hline B32 & 0.423 & 0.234 \\
\hline
\end{tabular}

Table 18. Ranks of alternative combinations based on results received using three MCDM methods

\begin{tabular}{|c|c|c|c|c|c|c|}
\hline $\begin{array}{c}\text { Alternative } \\
\text { combinations }\end{array}$ & Plinth & Wall & Roof & $\mathrm{MT}_{1}$ & $\mathrm{MT}_{2}$ & $\mathrm{MT}_{3}$ \\
\hline B1 & Plinth 1 & Wall 1 & Roof 1 & 11 & 11 & 11 \\
\hline B2 & Plinth 1 & Wall 1 & Roof 2 & 27 & 27 & 27 \\
\hline \multicolumn{7}{|c|}{$\vdots$} \\
\hline B10 & Plinth 2 & Wall 1 & Roof 2 & 19 & 18 & 19 \\
\hline B11 & Plinth 2 & Wall 2 & Roof 1 & 1 & 1 & 1 \\
\hline \multicolumn{7}{|c|}{$\vdots$} \\
\hline B32 & Plinth 4 & Wall 4 & Roof 2 & 22 & 21 & 22 \\
\hline
\end{tabular}

Conclusion: The best alternative, according to all three methods, was B11.

\section{Discussions}

It is mandatory to make the right modernisation decisions regarding the choice of the optimal energy efficiency solution before construction works start. The use of new technologies, such as BIM, for modernisation, would not only save time but also help to prevent the generation of a considerable number of possible modernisation solutions where policymakers can find the best option in an automated way by using programming algorithms already in the digital twin of an existing building. Besides, having a digital twin building with data, it is possible to simulate different scenarios for assuring that chosen modernisation solution meets all the requirements. In many cases, the BIM method is applicable for newly designed buildings, but this method can provide substantial benefit to old buildings too. What is more, it is easier to apply to other technologies when policymaker works in a digital environment. One of the methods to collect building geometry and other data is to use photogrammetry 
solution. Photogrammetry data serves as base data before design works. This technology saves time and provides higher accuracy for specific data collection and analysis. Created optimisation model using the BIM method, which is based on information management at various stages of the modernisation process: from the building audit and determination of the energy class of the building to the selection of the optimal modernisation option based on the MCDM method, reduces the potential human factors and inefficient solutions.

There are still many areas where the design and management of the modernisation process cannot be fully automated. The first steps in digital data collection could prevent the loss of information during the exchange between participants involved in project management.

The authors considering the research results think that this tested on a real building method would make an impact not only on energy efficiency but also on the cost of building maintenance. Saving costs on modernisation and the energy savings increase the economic value of the building in the long term and give benefits for selling or renting opportunities. In future research, it would be beneficial to evaluate modernised buildings using the proposed method and estimate the real benefit not only for the building owner but also to the users of this building after modernisation.

\section{Conclusions}

The suggested optimisation model identified the building elements involved in estimations of variation indicators. In terms of indoor energy consumption, significant energy simulation indicators of building elements were formulated, which had the most significant impact on the energy efficiency class. This Stage allowed finding rational variants that provided the best general energy indicators.

The multistage assessment of the variant matrix was adapted, and the decision tree helped to find the most rational variant. The SyMAD-3 method helps to summarise the results. The technique allowed a systemic selection of the most effective modification from composed alternatives.

The inventory of the building in Radviliškis was made using simple measurement techniques and the created photogrammetric model. This method permitted the creation of a unique digital model, which captured the real 3D geometric information of the building. This $3 \mathrm{D}$ model is fundamental for the adjustment of the BIM system as it can serve as a basis for modelling solutions with selected materials as well as allow developing a library of digital objects, linking it with other HVAC systems.

The condition of the building was assessed, and modernisation works were planned. This Stage allowed anticipating the decision-making model for the modernisation.

\section{References}

Banasik, A., Bloemhof-Ruwaard, J. M., Kanellopoulos, A., Claassen, G. D. H., \& van der Vorst, J. G. (2018). Multi-criteria decision making approaches for green supply chains: A review. Flexible Services and Manufacturing Journal, 30(3), 366-396. https://doi.org/10.1007/s10696-016-9263-5 
Barlish, K., \& Sullivan, K. (2012). How to measure the benefits of BIM - A case study approach. Automation in Construction, 24, 149-159. https://doi.org/10.1016/j.autcon.2012.02.008

Bortolini, R., \& Forcada, N. (2018). Facility managers' perceptions on building performance assessment. Frontiers Engineering Management, 5(3), 324-333. https://doi.org/10.15302/J-FEM-2018010

Bryde, D., Broquetas, M., \& Volm, J. M. (2013). The project benefits of Building Information Modelling (BIM). International Journal of Project Management, 31, 971-980. https://doi.org/10.1016/j.ijproman.2012.12.001

Chalal, M. L., Medjdoub, B., Bezai, N., \& Shrahily, R. (2020). Big Data to support sustainable urban energy planning: The EvoEnergy project. Frontiers Engineering Management, 7(2), 287-300. https://doi.org/10.1007\%2Fs42524-019-0081-9

Chong, H.-Y., Lee, C.-Y., \& Wang, X. (2017). A mixed review of the adoption of Building Information Modelling (BIM) for sustainability. Journal of Cleaner Production, 142(4), 4114-4126. https://doi.org/10.1016/j.jclepro.2016.09.222

Edirisinghe, R., London, K., Kalutara, P., \& Aranda-Mena, G. (2017). Building information modelling for facility management: are we there yet? Engineering, Construction and Architectural Management, 24(6), 1119-1154. https://doi.org/10.1108/ECAM-06-2016-0139

European Commission. (2011a). Energy efficiency plan 2011 (COM/2011/109 final). https://eur-lex. europa.eu/LexUriServ/LexUriServ.do?uri=COM:2011:0109:FIN:EN:PDF

European Commission. (2011b). Energy Roadmap 2050 (COM/2011/885 final). https://eur-lex.europa. eu/LexUriServ/LexUriServ.do?uri=COM:2011:0885:FIN:EN:PDF

European Commission. (2012). Communication from the Commission to the European Parliament and the Council-Strategy for the sustainable competitiveness of the construction sector and its enterprises (COM/2012/0433). https://eur-lex.europa.eu/LexUriServ/LexUriServ.do?uri=COM:2012:0433: FIN:EN:PDF

European Commission. (2014). A policy framework for climate and energy in the period from 2020 up to 2030 (COM/2014/16 final). https://eur-lex.europa.eu/legal-content/EN/ALL/?uri=CELEX\%3A $52014 \mathrm{DC} 0015$

European Union. (2010). Directive 2010/31/EU of the European Parliament and of the Council of 19 May 2010 on the energy performance of buildings (EPBD2010/31/EU). https://eur-lex.europa.eu/ legal-content/EN/ALL/?uri=CELEX\%3A32010L0031

Garcia, E. G., \& Zhu, Z. (2015). Interoperability from building design to building energy modelling. Journal of Building Engineering, 1, 33-41. https://doi.org/10.1016/j.jobe.2015.03.001

Goh, T. N. (1989). Some practical considerations in the design of manufacturing process experiments. Journal of Mechanical Working Technology, 20, 219-228. https://doi.org/10.1016/0378-3804(89)90032-6

Govindan, K., Shankar, K. M., \& Kannan, D. (2016). Sustainable material selection for construction industry - A hybrid multi criteria decision making approach. Renewable and Sustainable Energy Reviews, 55, 1274-1288. https://doi.org/10.1016/j.rser.2015.07.100

Gray, M., Gray, J., Teo, M., Chi, S., \& Cheung, F. (2013). Building information modeling, an international survey. Brisbane, Australia.

$\mathrm{Gu}, \mathrm{N}$., \& London, K. (2010). Understanding and facilitating BIM adoption in the AEC industry. Automation in Construction, 19, 988-999. https://doi.org/10.1016/j.autcon.2010.09.002

Habib, C., Makhoul, A., Darazi, R., \& Couturier, R. (2019). Health risk assessment and decision-making for patient monitoring and decision-support using wireless body sensor networks. Information Fusion, 47, 10-22. https://doi.org/10.1016/j.inffus.2018.06.008 
Habibi, S. (2017). Micro-climatization and real-time digitalization effects on energy efficiency based on user behavior. Building and Environment, 114, 410-428.

https://doi.org/10.1016/j.buildenv.2016.12.039

Hashemkhani Zolfani, S., Zavadskas, E. K., \& Turskis, Z. (2013). Design of products with both International and Local perspectives based on Yin-Yang balance theory and SWARA method. Economic Research-Ekonomska Istraživanja, 26(2), 153-166. https://doi.org/10.1080/1331677X.2013.11517613

He, Y., \& Xu, Z. (2019). Multi-attribute decision making methods based on reference ideal theory with probabilistic hesitant information. Expert Systems with Applications, 118, 459-469.

https://doi.org/10.1016/j.eswa.2018.10.014

Hemsath, T. L., \& Bandhosseini, K. A. (2017). Energy modeling in architectural design. Taylor \& Francis. https://doi.org/10.4324/9781315712901

Hu, M. (2019). Does zero energy building cost more? - An empirical comparison of the construction costs for zero energy education building in United States. Sustainable Cities and Society, 45, 324-334. https://doi.org/10.1016/j.scs.2018.11.026

Hwang, C., \& Yoon, K. (1981). Multiple attribute decision making: methods and applications: a state-ofthe-art survey. Springer-Verlag. https://doi.org/10.1007/978-3-642-48318-9_3

Ilce, A. C., \& Ozkaya, K. (2018). An integrated intelligent system for construction industry: A case study of raised floor material. Technological and Economic Development of Economy, 24(5), 1866-1884. https://doi.org/10.3846/20294913.2017.1334242

Jensen, P. A., Maslesa, E., Berg, J. B., \& Thuesen, C. (2018). 10 questions concerning sustainable building renovation. Building and Environment, 143, 130-137. https://doi.org/10.1016/j.buildenv.2018.06.051

Jia, Q., Wei, L., \& Li, X. (2019).Visualizing sustainability research in business and management (19902019) and emerging topics: a large-scale bibliometric analysis. Sustainability, 11(20), 5596. https://doi.org/10.3390/su11205596

Jose, P. C., Luis, B., \& Ricardo, M. (2019). Optimising building sustainability assessment using BIM. Automation in Construction, 102, 170-182. https://doi.org/10.1016/j.autcon.2019.02.021

Jung, Y., \& Joo, M. (2011). Building information modelling (BIM) framework for practical implementation. Automation in Construction, 20, 126-133. https://doi.org/10.1016/j.autcon.2010.09.010

Kaklauskas, A., Zavadskas, E. K., Raslanas, S., Ginevicius, R., Komka, A., \& Malinauskas, P. (2006). Selection of Low-E windows in retrofit of public buildings by applying multiple criteria method COPRAS: A Lithuanian case, Energy and Buildings, 38(5), 454-462.

https://doi.org/10.1016/j.enbuild.2005.08.005

Kamari, A., Schultz, C. P. L., \& Kirkegaard, P. H. (2019). Constraint-based renovation design support through the renovation domain model. Automation in Construction, 104, 265-280. https://doi.org/10.1016/j.autcon.2019.04.023

Kaya, I., Çolak, M., \& Terzi, F. (2018). Use of MCDM techniques for energy policy and decision-making problems: A review, International Journal of Energy Research, 42(7), 2344-2372. https://doi.org/10.1002/er.4016

Kreider, R., Messner, J., \& Dubler, C. (2010). Determining the frequency and impact of applying BIM for different purposes on projects. Paper presented at the Proceeding 6th International Conference on Innovation in Architecture, Engineering and Construction (AEC), Pennsylvania State University, University Park, PA, USA.

Kreiner, H., Passer, A., \& Wallbaum, H. (2015). A new systemic approach to improve the sustainability performance of office buildings in the early design stage. Energy and Buildings, 109, 385-396. https://doi.org/10.1016/j.enbuild.2015.09.040 
Krylovas, A., Kosareva, N., \& Zavadskas, E. K. (2018). Scheme for statistical analysis of some parametric normalization classes. International Journal of Computers, Communications \& Control (IJCCC), 13(6), 972-987. https://doi.org/10.15837/ijccc.2018.6.3398

Kumar, A., Sah, B., Singh, A. R., Deng, Y., He, X., Kumar, P., \& Bansal, R. C. (2017). A review of multi criteria decision making (MCDM) towards sustainable renewable energy development. Renewable and Sustainable Energy Reviews, 69, 596-609. https://doi.org/10.1016/j.rser.2016.11.191

Lee, K. H., Kim, I. H., \& Choo, S. Y. (2015). Model study of design components for energy-performance-based architectural design using BIM LOD 100. Journal of Green Building, 10(2), 179-197. https://doi.org/10.3992/jgb.10.2.179

Leite, F., Akcamete, A., Akinci, B., Atasoy, G., \& Kiziltas, S. (2011). Analysis of modeling effort and impact of different levels of detail in building information models. Automation in Construction, 20, 601-609. https://doi.org/10.1016/j.autcon.2010.11.027

Linderoth, H. (2010). Understanding adoption and use of BIM as the creation of actor networks. Automation in Construction, 19(1), 66-72. https://doi.org/10.1016/j.autcon.2009.09.003

MacCrimmon, K. R. (1968). Decision-making among multiple-attribute alternatives: a survey and consolidated approach (DTIC Document).

Maghsoodi, A. I., Abouhamzeh, G., Khalilzadeh, M., \& Zavadskas, E. K. (2018). Ranking and selecting the best performance appraisal method using the MULTIMOORA approach integrated Shannon's entropy. Frontiers of Business Research in China, 12(1), 2-21. https://doi.org/10.1186/s11782-017-0022-6

Mahdavi, A., \& Tahmasebi, F. (2015). Predicting people's presence in buildings: An empirically based model performance analyses. Energy and Buildings, 86, 349-355.

https://doi.org/10.1016/j.enbuild.2014.10.027

Mahdiraji, H. A., Turskis, Z., Jafarnejad, A., \& Rezayar, A. (2019). Non-cooperative two-echelon supply chains with a focus on social responsibility. Technological and Economic Development of Economy, 25(6), 1162-1187. https://doi.org/10.1108/mbe-11-2014-0041

Martinaitis, V., Zavadskas, E. K., Motuzienė, V., \& Vilutienė, T. (2015). Importance of occupancy information when simulating energy demand of energy efficient house: A case study. Energy and Buildings, 101, 64-75. https://doi.org/10.1016/j.enbuild.2015.04.031

Merschbrock, C., \& Figueres-Munoz, A. (2015). Circumventing obstacles in digital construction design - a workaround theory perspective. Procedia Economics and Finance, 21, 247-255. https://doi.org/10.1016/S2212-5671(15)00174-4

Ministry of Environment of the Republic of Lithuania (2016). Construction technical regulation "Design and certification of energy performance of buildings" (STR 2.01.02:2016). https://www.e-tar.lt/portal/ en/legalAct/2c182f10b6bf11e6aae49c0b9525cbbb

Nazarko, L., \& Melnikas, B. (2019). Operationalising responsible research and innovation - tools for enterprises. Engineering Management in Production and Services, 11(3), 21-28. https://doi.org/10.2478/emj-2019-0017

Pinheiro, S., Donnell, J., Wimmer, R., Bazjanac, V., Muhic, S., Maile, T., Frisch, J., \& Treeck, C. (2018). Model view definition for advanced building energy performance simulation. Paper presented at the CESBP/BauSIM 2016 Conference, Dresden, Berlin. http://www.ibpsa.org/proceedings/ bausimPapers/2016/D-02-1.pdf

Radović, D., Stević, Ž., Pamučar, D., Zavadskas, E. K., Badi, I., Antuchevičiene, J., \& Turskis Z. (2018). Measuring performance in transportation companies in developing countries: a novel rough ARAS model. Symmetry, 10(10), 1-24. https://doi.org/10.3390/sym10100434

Rodrigues, F., Matos, R., Alves, A., Ribeirinho, P., \& Rodrigues, H. (2018). Building life cycle applied to refurbishment of traditional building from Oporto, Portugal. Journal of Building Engineering, 17, 84-95. https://doi.org/10.1016/j.jobe.2018.01.010 
Ruzgys, A., Volvačiovas, R., Ignatavičius, Č., \& Turskis, Z. (2014). Integrated evaluation of external wall insulation in residential buildings using SWARA-TODIM MCDM method. Journal of Civil Engineering and Management, 20(1), 103-110. https://doi.org/10.3846/13923730.2013.843585

Saaty, T. L. (1994). Fundamentals of decision making and priority theory with the AHP. RWS Publications.

Salman, A. (2011). Building Information Modeling (BIM): trends, benefits, risks, and challenges for the AEC industry. Leadership and Management in Engineering, 11(3), 241-252. https://doi.org/10.1061/(ASCE)LM.1943-5630.0000127

Siksnelyte, I., Zavadskas, E. K., Streimikiene, D., \& Sharma, D. (2018). An overview of multi-criteria decision-making methods in dealing with sustainable energy development issues. Energies, 11(10), 1-21. https://doi.org/10.3390/en11102754

Simanaviciene, R., \& Ustinovichius, L. (2012). A new approach to assessing the biases of decisions based on multiple attribute decision making methods. Elektronika ir elektrotechnika, 117(1), 29-32. https://doi.org/10.5755/j01.eee.117.1.1048

Simanaviciene, R., Liaudanskiene, R., \& Ustinovichius, L. (2012). A new synthesis method of structural, technological and safety decisions (SyMAD-3). Journal of Civil Engineering and Management, 18(2), 265-276. https://doi.org/10.3846/13923730.2012.666504

Somboonwit, N., Boontore, A., \& Rugwongwan, Y. (2017, February 25-27). Obstacles to the automation of building performance simulation: adaptive building integrated photovoltaic (BIPV) design. Paper presented at the 5th AMER International Conference on Quality of Life, Bangkok, Thailand. https://doi.org/10.21834/e-bpj.v2i5.619

Turskis, Z., Zavadskas, E. K., \& Kutut, V. (2013). A model based on ARAS-G and AHP methods for multiple criteria prioritizing of heritage value. International Journal of Information Technology \& Decision Making, 12(01), 45-73. https://doi.org/10.1142/S021962201350003X

Volk, R., Stengel, J., \& Schultmann, F. (2014). Building Information Modeling (BIM) for existing buildings-Literature review and future needs. Automation in Construction, 38, 109-127. https://doi.org/10.1016/j.autcon.2013.10.023

Wang, N., \& Adeli, H. (2015). Self-constructing wavelet neural network algorithm for nonlinear control of large structures. Engineering Applications of Artificial Intelligence, 41, 249-258. https://doi.org/10.1016/j.engappai.2015.01.018

Winkowski, C. (2019). Classification of forecasting methods in production engineering. Engineering Management in Production and Services, 11(4), 23-33. https://doi.org/10.2478/emj-2019-0030

Yazdani, M., Zarate, P., Zavadskas, E. K., \& Turskis, Z. (2019). A Combined Compromise Solution (CoCoSo) method for multi-criteria decision-making problems. Management Decision, 57(9), 2501-2519. https://doi.org/10.1108/MD-05-2017-0458

Yin, X., Liu, H., Chen, Y., \& Al-Hussein, M. (2019). Building information modelling for off-site construction: Review and future directions. Automation in Construction, 101, 72-91. https://doi.org/10.1016/j.autcon.2019.01.010

Zavadskas, E. K., Antucheviciene, J., Saparauskas, J., \& Turskis, Z. (2013). MCDM methods WASPAS and MULTIMOORA: verification of robustness of methods when assessing alternative solutions. Economic Computation and Economic Cybernetics Studies and Research, 47(2), 5-20.

Zavadskas, E. K., Antucheviciene, J., Turskis, Z., \& Adeli, H. (2016a). Hybrid multiple-criteria decisionmaking methods: A review of applications in engineering. Scientia Iranica. Transaction A, Civil Engineering, 23(1), 1-20. https://doi.org/10.24200/sci.2016.2093

Zavadskas, E. K., Govindan, K., Antucheviciene, J., \& Turskis, Z. (2016b). Hybrid multiple criteria decision-making methods: A review of applications for sustainability issues. Economic ResearchEkonomska Istraživanja, 29(1), 857-887. https://doi.org/10.1080/1331677X.2016.1237302 
Zavadskas, E. K., Kaklauskas, A., \& Sarka, V. (1994). The new method of multicriteria complex proportional assessment of projects. Technological and Economic Development of Economy, 1(3), 131-139.

Zavadskas, E. K., Kaklauskas, A., Banaitis, A., \& Kvederyte, N. (2004). Housing credit access model: The case for Lithuania. European Journal of Operational Research, 155(2), 335-352. https://doi.org/10.1016/S0377-2217(03)00091-2

Zavadskas, E. K., Kaklauskas, A., Turskis, Z., \& Kalibatas, D. (2009). An approach to multi-attribute assessment of indoor environment before and after refurbishment of dwellings. Journal of Environmental Engineering and Landscape Management, 17(1), 5-11. https://doi.org/10.3846/1648-6897.2009.17.5-11

Žèkas, V., Martinaitis, V., Streckienė, G., \& Vilutienè, T. (2014). A quantitative evaluation of theoretical renewable energy potential of the building site. Journal of Civil Engineering and Management, 20(6), 873-883. https://doi.org/10.3846/13923730.2014.976589

Zemlickiene, V., \& Turskis, Z. (2020). Evaluation of the expediency of technology commercialization: a case of information technology and biotechnology. Technological and Economic Development of Economy, 26(1), 271-289. https://doi.org/10.3846/tede.2020.11918

Zou, X. W. P., Alam, M., Phung, V. M., Wagle, D., Stewart, R., Bertone, E., Sahin, O., \& Butine, C. (2017). Achieving energy efficiency in government buildings through mandatory policy and program enforcement. Frontiers Engineering Management, 4(1), 92-103.

https://doi.org/10.15302/J-FEM-2017101 